\title{
Exploring the Effectiveness of Learning Activities in Physics Using Indigenous Materials During Pandemic
}

\author{
Mary Rose Fabila Santos ${ }^{a^{*}}$, Dennis Gamad Caballes ${ }^{b}$ \\ Corresponding Author: maryrose75santos@gmail.com \\ Antipolo City Senior High School, Antipolo City, Philippines \\ Centro Escolar University, Mendiola St. San Miguel, Manila, Philippines
}

\begin{abstract}
This study aimed to explore the effectiveness of learning activity using indigenous material in physics at Antipolo City Senior High school. The use of indigenous materials in learning activities will serve as substitute materials for conducting laboratory activities of students at home during this pandemic. The respondents of this study are the grade 12 students of Antipolo City Senior High School during the school year 2020-2021. A questionnaire was administered in two sections of grade 12 STEM students.

The findings of this study show that the designed learning activities in Physics using locally, ready and available materials were found very suitable and effective as a substitute for laboratory equipment used in school amidst this pandemic.

The newly designed learning activities using indigenous materials are highly recommended for the use of the Senior High School students who will take a Physics course with or without pandemic. Moreover, Science teachers are encouraged to become resourceful in designing more learning activities or laboratory experiments with the utilization of local or indigenous materials not only as a substitute for science equipment but to tap the availability of the local community's resources for producing its own genuine locally made products or science equipment.
\end{abstract}

Keywords: learning activity; effectiveness; indigenous materials, pandemic

\section{Introduction}

K-12 Curriculum in science education aims to help learners develop the desired learning competencies that are crucial in the world of work and knowledge-based society.

Teachers are believed to be designers of learning activities that help learners attain course learning outcomes. The global pandemic has affected much all aspects of life especially the education of children. For making education possible amidst this pandemic, the Department of Education (DepEd) has trained teachers to equip themselves with the latest online learning platforms. This pandemic makes us all indoor educators and learners that limit physical interaction among the living to ensure that there is a minimum health standard. Despite so many restrictions and lack of equipment, education survives with the strong commitment of teachers who are also front liners to deliver educational services to the community. The distribution of learning modules is done by the teachers in the local communities to ensure that the goal of education is attained. 
The COVID-19 pandemic changed learning in many prodigious ways. It was quite difficult for some to fix the 'new normal' and didn't get someone in touch with their teachers. Schools need to know how students feel about a distant education and learn more about their experiences. Staying at home all the time and balancing a lot of things can be stressful. It requires students to develop positive management skills and self-discipline. As the government prohibits face-to-face interaction and mass gatherings, DepEd's blended learning approach has been implemented using television, radio, printed materials, and the internet. DepEd comes up with distance learning delivery methods that ensure the safety of learners when they are studying. Surveys are performed to evaluate the preferred learning strategies for parents to provide to their children. Many parents prefer a modular distance learning solution because they cannot afford to provide internet access for their children's online learning. The adaptive learning methods for learners amid the COVID-19 pandemic must be implemented. According to (Li \& Lalani, 2020), the COVID-19 pandemic resulted in more than 1.2 billion children is not in the classroom worldwide. The sudden shift away of teaching modalities leads to students and teachers a new daily virtual routine that replaces in-class instruction. From a teachers' perspective on distance learning, they cannot fully be sure that students participate in class because of the comfort of their own homes. Distance education lacks proximity with teachers and has its own range of unique challenges. Some students may find it difficult to learn a topic and take more time to understand it. Some of the changes in the educational system include the absence of laboratory activities and apparatus. As (Landicho, 2021) stressed his own experience as an Earth science teacher, one of the adjustments in the current situation includes the absence of laboratory activities, field visits, and the shift to online delivery of lessons. These changes include redesigning lessons and assessments, the limitations on technology, and the effects of reducing social interaction with students and teachers.

Teaching physics in school can consecrate a reward, with lots of excitement and creative problems solving. This includes helping students see the world in a new way. It involves studying an environment where students are searching and understanding how the physical world works. Students learn best when they're involved in the learning. They need their multiple senses to engage in hands-on science activities. Critical thinking skills are enhanced during such science activities and they can learn the scientific process along the way. Science teachers believe that student practical work leads to better learning. They all understand and remember things better if they engage in the learning activities. Some science teachers see practical work as an essential element of good science teaching. (Abrahams \& Millar, 2008).

(Redish \& Steinberg, 1999) assert that careful observation and analysis of physics content and the behavior of experts is necessary. How our students hear and explain the material presented to them in a physics class relies heavily on the experiences they bring to the class. To design effective instruction, teachers must learn how students really respond. (Saiqa, 2018) likewise mentioned in his study that knowledge about the topic teachers needs to be taught is always considered an important preparation for teachers. It follows that physics teachers need to have a deeper understanding of the concepts they need to teach to the learner. Teachers know how our students learn in many different ways. Hands-on activities allow them to explore experiments with trials and error. Hands-on experiences also provide teachers with a unique opportunity to enrich the minds of their students in new and engaging ways. Moreover, (Centra \& Gaubatz, 2005) also indicate that student learning is highly influenced by the effort students put forward. Although an instructor can do much to facilitate learning and provide some motivation, ultimately students themselves must take some responsibility for their learning in a course. (Dhanapal \& Zi Shan, 2014) emphasized that there is typically a higher level of participation and intrinsic motivation shown to students when they learned through hands-on experiments. Considering that learning is an active process in activity-based education, it is needed to prioritize activities in order to create education environments that lead students to learn by doing and experiencing. (Celik, 2018). 
As the article of (Simamoraa et al., 2017) indicated that activity is a very important thing in the teaching-learning process. Student's activities will be more effective with a better teaching-learning design to grab knowledge or skill. Each student has a desire to do and work alone without instruction from their teacher. This active principle controls student behavior. Before implementing any activities, the teachers need to understand the priorities and needs of the students. The present study is intended to explore the effectiveness of learning activities in Physics using indigenous materials amid this pandemic. Indigenous materials are raw materials and objects that are naturally and locally available or found in the neighboring communities. Indigenous materials are renewable and abundant, coming from diverse natural sources and whose production has a low impact on the environment. It is naturally nonpolluting, emitting no harmful vapors, particles, or toxins into the environment. These materials are at low risk, high benefit activities that require less time and money. A potential learning activity heightens physiological arousal in the brain, which makes the performance more efficient.

As a newly stand-alone Senior High School, the researcher has been struggling to improve the performance of the students in Physics. Learning materials are a very essential part of teaching and learning. The researcher as a teacher-writer of SAS (Students Learning Activity Sheets), designed a learning activity that uses indigenous materials that are naturally and locally available or found in the community.

\section{Materials and Methods}

\subsection{Statement of the Problem}

This study aimed to determine the effectiveness of learning activities using indigenous material in Physics at Antipolo City Senior High School.

Specifically, it aimed to answer the following questions:

1. In what ways the learning activities of students using indigenous materials are effective?

2.Could the indigenous materials be used as substitutes in the absence of laboratory physics apparatuses?

\subsection{Methods}

The respondents of this study are the 66 Grade 12 STEM students of Antipolo City Senior High School during the school year 2020-2021. The researcher developed 20 questions survey questionnaire and distributed it to the respondents. Their responses for each item were tallied, analyzed, and interpreted using Likert Type Mean Interpretation. The interpreted Mean for Strongly Agree corresponds to Highly Acceptable and Agree to Acceptable as the level of acceptance. The findings of the study will be helpful for the teachers to design learning activities which are most appropriate to the learning needs of students during this pandemic.

The learning activities have been developed to strengthen students' understanding of important physics concepts. Simple Learning Objectives are specifically stated in each Learning Activity title.

The challenge for teaching is to use learning activities that will encourage students to be interactive, productive and creative. Such activities need to be energetic and memorable in themselves, as well as being aligned to an academic outcome. The designed learning activities make use of indigenous materials as a substitute for laboratory equipment used in school amidst this pandemic. This practice should make the laboratory less expensive to maintain. 


\subsection{Conceptual Framework}

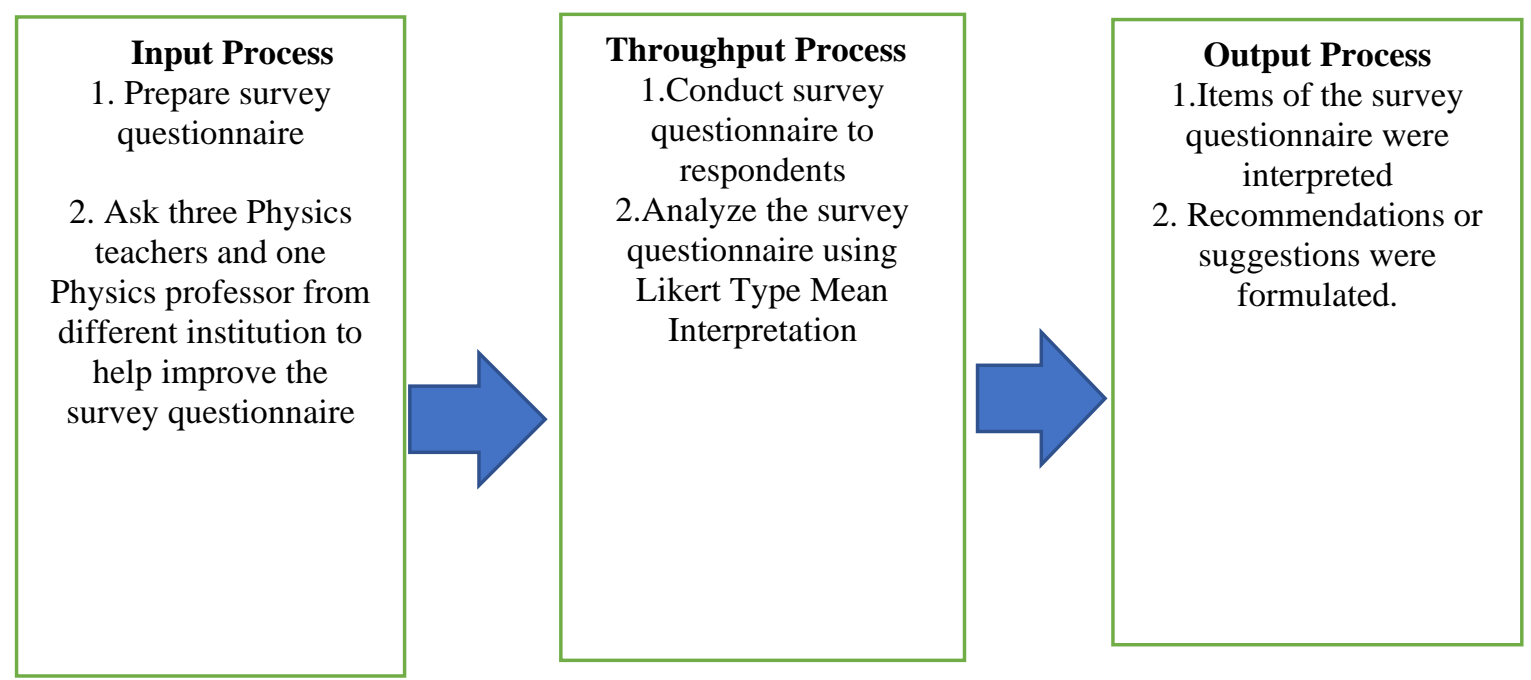

In the input process, prepared a survey questionnaire and asked colleagues of the same field and one college physics professor to evaluate the questionnaire. In the throughput process, the researcher conducted a survey to the respondents, analyzed and interpreted the answered survey questionnaire using Likert-type mean interpretation. In the output process, 20 items in the survey questionnaire were interpreted and the researcher made some recommendations.

\section{Results and Discussions}

Based on gathered data, item number 1 was rated as strongly agreed by the respondents. This shows that students were able to understand the objectives of the learning activities behaviorally. It is important to note that many objectives are written in a manner in which the essential conditions and criteria are implied.

(Kizlik, 2019) indicates that properly developed behavioral learning objectives show evidence of learning, and this refers to what kind of learning behavior should be developed the teacher would expect. To write down the learning objectives, one should begin by understanding the specific content where the objectives can be drawn. This implies that a learning objective clearly conveys specific student behavior or performance. However, item number 2 interpreted as strongly agreed by the students. It shows that the objectives are clear and relevant to the learning activity. This implies also that the objectives clearly communicate and describe the intended learning outcome. In item number 9, it confirms that students strongly agreed with the language used in the learning activities which is suitable to the student's level of comprehension. By means of using the learning activities, teachers increase students' interests and motivations to perform the activity. Critical thinking activities must be developed by the students while 
performing the activity. A very strong indication shows that students strongly agreed with item 11 in which learning activities can develop critical thinking skills. In addition, engaging students in exploring questions provide a way to develop sharp critical thinking skills. However, item number 12 shows also a strong indication as strongly agreed that the learning activities gave the opportunity for the students to discover for themselves the concept being studied. On the other hand, item no.19 also interpreted as strongly agreed by the students indicates that the indigenous materials in the learning activities are easy and safe to use. Local materials or indigenous materials are easily and readily available. It can be obtained free or at a low cost. Selecting and identifying local materials or resources for making learning activities will help students become resourceful and creative. This also implies that the indigenous materials used in the learning activities are environmentally friendly. The rest of the items were rated as agreed by the respondents. It can be concluded that the designed learning activities in Physics using locally, ready and available materials were found very effective as a substitute for laboratory equipment used in school amidst this pandemic.

Table 1. Students' Perceptions on the Objectives and Procedures of Learning Activity

\begin{tabular}{cccc}
\hline Item & $\overline{\mathrm{x}}$ & Interpretation of $\overline{\mathrm{x}}$ & Level of Acceptance \\
\hline 1 & 4.27 & Strongly Agree & Highly Acceptable \\
2 & 4.25 & Strongly Agree & Highly Acceptable \\
3 & 4.17 & Agree & Acceptable \\
4 & 3.95 & Agree & Acceptable \\
5 & 3.5 & Agree & Acceptable \\
& $\mathrm{G} \overline{\mathrm{x}}=4.028$ & Agree & Acceptable \\
\hline
\end{tabular}

Table 1 shows that items 1 and 2 were rated as Strongly Agree correspond to Highly Acceptable as the level of acceptance. It indicates that the objectives are behaviorally stated, clear and relevant to the learning activity. However, items 3, 4, 5 interpreted as Agree correspond to Acceptable as the level of acceptance because the objectives are measurable and attainable. It also shows that the procedure on how to go about the learning activities is clearly presented and the steps in the procedure are easy to follow even without much help from the teacher. (Abanador et al., 2014) mentioned that in teaching, the method is a systematic plan to achieve a learning objective. It is a procedure that must be followed strictly to attain a goal. It refers to a series of related and progressive acts performed by the teacher and students to achieve the objectives of the lesson. It is a well-planned procedure that guides the direction in undertaking a learning activity. The article of (Timothy, 2016) indicates that in order to use learning activities appropriately and impressively, it, therefore, becomes imperative to align these with the learning objectives. In order to make the learning objectives successful, it is essential that these objectives are supplemented with the right tools.

Table 2. Students' Perceptions on the Clarity of Procedures, Diagrams, and Language Used in the Learning Activity

\begin{tabular}{cccc}
\hline Item & $\overline{\mathrm{x}}$ & Interpretation of $\overline{\mathrm{x}}$ & Level of Acceptance \\
\hline 6 & 4.03 & Agree & Acceptable \\
7 & 4.12 & Agree & Acceptable \\
8 & 4.12 & Agree & Acceptable \\
9 & 4.27 & Strongly Agree & Highly Acceptable
\end{tabular}


Acceptable

$$
\mathrm{G} \overline{\mathrm{x}}=4.138
$$

Agree

Acceptable

Table 2 shows that item 9 interpreted as Strongly Agree corresponds to Highly Acceptable as the level of acceptance. It means that the language used in the learning activities is suitable to the student's level of comprehension. However, items 6, 7, 8, and 10 were rated as Agree correspond to Acceptable as the level of acceptance. It indicates that the illustrations and diagrams are provided and well laid out, properly drawn, and labeled. The learning activities are logically arranged. Also, the questioning in the learning activities can lead the students to the concept being presented. Lastly, the learning activities can arouse the students' curiosity and interest. Similarly in the study of (Seven \& Engin, 2007) has been found out that according to the students' answers for the questionnaire and point of views that language teaching materials are having a very important effect and role in language learning and teaching activities.

(Yakob et al., 2020) emphasized that one effective way of exploring students 'curiosity is by applying experiments in learning activities from which students can ably think rationally and scientifically. Learning that is implemented optimally can increase creativity and motivation in learning activities, especially in terms of the quality of education. Through hands-on experiments and practical activities in Physics, students would have improved and developed their learning, practical skills, problem-solving, analytical skills, and positive attitudes towards science ((Cziprok et al., 2015). However, when teachers instruct the language in a given science unit, students can more easily understand the concepts. (Wilson, 2002).

Table 3. Students' Attitudes on the Use of Learning Activity

\begin{tabular}{cccc}
\hline Item & $\overline{\mathrm{x}}$ & Interpretation of $\overline{\mathrm{x}}$ & Level of Acceptance \\
\hline 11 & 4.28 & Strongly Agree & Highly Acceptable \\
12 & 4.2 & Strongly Agree & Highly Acceptable \\
13 & 3.95 & Agree & Acceptable \\
14 & 3.62 & Agree & Acceptable \\
& $\mathrm{G} \overline{\mathrm{x}}=4.0125$ & Agree & Acceptable \\
\hline
\end{tabular}

In table 3, items 11 and 12 show a very strong indication that the learning activities give an opportunity for the students to discover for themselves the concept being studied. It also shows that the learning activities can develop students' critical thinking. Moreover, items 13 and 14 interpreted as Agree. It shows that the number of questions is enough to test the understanding of the concepts learned from the activity. Besides, the style of format of the learning activities makes the activity enjoyable to read and follow. As (James, 2015) stated that connecting students' previous knowledge and experiences and highlighting the value of an assigned activity in relevant ways can ensure that activities are personally meaningful. To strengthen students' sense of competence in learning activities, the assigned activities could make students demonstrate understanding throughout the activity and include feedback that helps students to make progress. Learning is enhanced if students can manage it themselves. They need to establish goals, persevere, and monitor their learning progress. Research has also shown that learning is more likely to be effective where a 
student plays a proactive role in the learning process. Students who are intrinsically motivated to learn mathematics or science find the subject to be interesting and enjoyable. (Hooper, 2019).

Table 4. Students' Perceptions on the Use of Indigenous Materials in the Learning Activity

\begin{tabular}{cccc}
\hline Item & $\overline{\mathrm{x}}$ & Interpretation of $\overline{\mathrm{x}}$ & Level of Acceptance \\
\hline 15 & 3.71 & Agree & Acceptable \\
16 & 3.73 & Agree & Acceptable \\
17 & 3.78 & Agree & Acceptable \\
18 & 3.88 & Agree & Acceptable \\
19 & 4.22 & Strongly Agree & Highly Acceptable \\
20 & 4.1 & Agree & Acceptable \\
& $\mathrm{G} \overline{\mathrm{x}}=3.903$ & Agree & Acceptable \\
\hline
\end{tabular}

Item 19 interpreted as Strongly Agree corresponds to Highly Acceptable. This shows that the indigenous materials in the learning activities are easy and safe to use by the students. However, items 15, 16, 17, 18, and 20 were rated Agree correspond to Acceptable as the level of acceptance. The data also revealed that the indigenous materials used in the activities save money and time. The indigenous materials used in the learning activities are locally available and environmentally friendly. It also develops students' creativity and resourcefulness.

(Castaneda, 2016) stressed the utilization of indigenized instructional materials designed using a leftover piece of wood. The study revealed that the IM designed is very effective attaining the highest percentage of correct response and percent of achievement attained. Moreover, (Onasanya \& Omosewo, 2011) emphasized that using improvised instructional materials helps the teacher economically, allows students interaction, and makes students use their intellectual ability during learning and teaching processes. In other words, students may acquire more knowledge and information thru the use of several instructional materials to bring a deeper understanding of the topics under consideration.

Quality learning materials are crucial in teaching physics. Science should be taught in such a way that students are exposed to real and practical related activities (Udosen \& Ekukinam, 2013). Some science teachers believe that student practical work leads to better learning because they all understand and remember things better if they have done them ourselves It also is important to consider the context within which specific materials will be used. Learning materials are important because they can significantly increase student achievement by supporting student learning. Using locally and readily available materials in learning activities provides a student with important opportunities to practice a new skill gained. Getting hands-on valuable teaching materials is not nearly as difficult as it can seem at first. Learning materials, regardless of what kind, all have some function in student learning.

Moreover, (Fredricks et al., 2004) revealed that if students do not consider a learning activity worthy of their time and effort, they might not engage in a satisfactory way, or may even disengage entirely in response. Learning activities are personally meaningful if there is a connection to students' previous knowledge and experiences. Students' perspective of learning activities also determines their level of 
engagement. It is more likely to be full and thorough (Anderman \& Patrick, 2012). Also, when students work effectively or collaboratively with others, their engagement may be strengthened as a result (Wentzel, 2009). The challenge for teaching is to select learning materials that will encourage students to work independently and effectively with their learning activities.

The article of (Zingiswa, 2015) stressed that the activities in which the learners were engaged during the course of this study involved a combination of cultural aspects using indigenous material and an allowance of learners to work in a classroom environment freely allowing learners to apply their insights and experiences. Similarly, the study of (Shih et al., 2011) showed that the environment plays an important role in enhancing students' motivation and learning effectiveness. Furthermore, the present study explored the effectiveness of learning activities using indigenous materials. The use of indigenous materials in learning activities was found very suitable and effective. Indigenous materials are naturally occurring and abundant in nature. It is locally produced and manufactured. The use of indigenous materials is recommended because it is environmentally friendly, accessible, and costs less. (Tuimur \& Chemwei, 2015). mentioned that resource materials allow learners to have practical experiences which help them to develop skills and concepts and to work in a variety of ways. The present study designed learning activities, used and produced from the available local materials as a substitute for laboratory equipment used in school amidst this pandemic. The used of indigenous materials in learning activities not only lessens the energy and operation costs but it also helps the sustainability of these materials and shows pride on our products. These materials were found to be suitable and effective to enhance effective teaching and learning of science in school that are unable to afford expensive laboratory materials. Students are made to use the various materials and experiment with different techniques to improve their overall science literacy. Science learning activities aid in developing scientific learning amongst students, and in cultivating deeper and profound interest in the field. Teaching science requires a different approach. On the other hand, teachers have to provide opportunities to their students to learn the various methods and processes. By means of using the local and readily available materials, teachers increase students' interests and motivations to the subjects and lessons. Science teachers should be encouraged to make their own teaching resources from the locally available materials to teach science. There is a need for teachers to use indigenous materials in place of the laboratory equipment to enhance teaching and learning especially in rural areas where resources are scarce. These materials are cheaper, safer and develop students' creativity and understanding in manipulating of real objects and materials.

\section{Conclusions and Recommendations}

Based on the findings of the study, the respondents have Strongly agreed with items 1, 2, 9, 11, 12, and 19. However, these items correspond to Highly Acceptable as the level of acceptance. The rest of the items were rated as agreed by the respondents. This only implies that the the designed learning activities in Physics using locally, ready and available materials were found very suitable and effective as a substitute for laboratory equipment used in school amidst this pandemic.

The newly designed learning activities using indigenous materials are highly recommended for the use of the Senior High School students who will take a Physics course with or without pandemic. There must be a moral support from the school administrator so that the science teacher will be much more encouraged to design learning activities for the utilization of indigenous material which are available in the local community. Since the internet connection is unstable and majority of the students in public school cannot afford to pay the monthly subscription of the internet, an alternative for the online learning is to engage students do the learning activities using local materials in their house during this pandemic. 
Moreover, Science teachers are encouraged to become resourceful in designing more learning activities or laboratory experiments with the utilization of local or indigenous materials not only as a substitute for science equipment but to tap the availability of the local community's resources for producing its own genuine locally made products or science equipment.

\section{REFERENCES}

Abanador, Jeamarie R. Guillian Christine D. Buesa, Guada Marie L. Remo, Jovielyn Mañibo (2014).

Teaching Methods and Learning Preferences in the Engineering Department of an Asian University; ISSN: 2226-6348. http://dx.doi.org/10.6007/IJARPED/v3-i1/499

Abrahams Ian, Millar, Robin (2008). Does Practical Work Really Work? A study of the effectiveness of practical work as a teaching and learning method in school science; Pages 1945-1969; https://doi.org/10.1080/09500690701749305

Anand Timothy (2016). Learning Objectives Vs Learning Activities: What's the Difference? https://elearningindustry.com/learning-objectives-vs-learning-activities

Anderman, E. M., \& Patrick, H. (2012). Achievement goal theory, conceptualization of ability/intelligence and classroom climate. In S. Christenson, A. Reschly, \& C. Wylie (Eds.), Handbook of Research on Student Engagement (pp. 173-191). New York, NY: Springer.

Castaneda, Myrna (2016) Indigenized Instructional Materials for Science 8 and 9 https://www.slideshare.net/myrnacastaneda/indigenized-instructional

Celik, Halil Coşkun (2018). The Effects of Activity Based Learning on Sixth Grade Students' Achievement and Attitudes towards Mathematics Activities. EURASIA Journal of Mathematics, Science and Technology Education, 2018, 14(5), 1963-1977

Cziprok, Daniela, Claudia, Popescu, F. F., Ioan, Pop Alexandru, \& Andrei, Variu (2015). Conceptual Maps and Integrated Experiments for Teaching/Learning Physics of Photonic Devices. Procedia - Social and Behavioral Sciences, 191, 512-518. doi: 10.1016/j.sbspro.2015.04.284

Centra, John A. and Noreen B. Gaubatz (2005). Students Perceptions of Learning and Instructional Effectiveness in College Courses. https://www.ets.org/Media/Products/perceptions.pdf

Dhanapal, Saroja, Evelyn Wan Zi Shan (2014). A Study on the Effectiveness of Hands- on Experiments in Learning Science among Year 4 Students; ISSN: 1300-915X. http://www.ijtase.net/ojs/index.php/IOJPE/article/view/223

Fredricks, J. A., Blumenfeld, P. C., \& Paris, A. H. (2004). School engagement: Potential of the concept, state of the evidence. Review of Educational Research, 74(1), 59-109. http://www.jstor.org/stable/3516061

Hooper, Martin Ina V.S. Mullis, Mi Martin, Michael O. and Bethany Fishbein (2017). Student Attitudes Toward Mathematics and Science. https://timssandpirls.bc.edu/timss2019/frameworks/framework-chapters/context-questionnaireframework/student-attitudes-toward-learning

James, Nicolas Pino (2015). Golden Rules for Engaging Students in Learning Activities. Edutopia. https://www.edutopia.org/blog/golden-rules-for-engaging-students-nicolas-pino-james

Kizlik, Bob (2019). How to Write Learning Objectives that Meet Demanding Behavioral Criteria. https://www.adprima.com/objectives.htm

Landicho, Christoper Jan B. (2021). Changes, Challenges, and Opportunities in Teaching Senior High School Earth Science amidst the COVID-19 Pandemic; Vol. 6, no. 1 pp. 55 - 57. https://doaj.org/article/7b9a3011cdf5494196924fac3e85b2b8 
Li, C. Lalani, F. (2020). The Covid-19 pandemic has changed education forever.

https://www.weforum.org/agenda/2020/04/coronavirus-education-global-covid19-online-digital- learning/

Onasanya, S. A. Omosewo, E. Q. (2011). Effect of Improvised and Standard Instructional Materials on Secondary School Students' Academic Performance in Physics in Ilorin, Nigeria. Pp. 68-76 https://scialert.net/abstract/?doi=sjsres.2011.68.76

Redish, Edward F. Steinberg, Richard N. (1999). Teaching Physics: Figuring Out What Works. Physics Today, Vol. 52 pp. 24-30. https://www.physics.umd.edu/perg/papers/redish/pt.htm

Saiqa Azam;( 2018). Physics for Teaching High School Physics: Views of Prospective Physics Teachers and Teacher Educators about Undergraduate Physics Study; Journal of Teacher Education and Educators Volume 7, Number 2, 2018, 147- 163. https://files.eric.ed.gov/fulltext/EJ1207272.pdf

Seven, Mehmet Ali; Engin, Ali Osman (2007). The Importance and Effect of Using Aid Materials in Foreign Language Teaching. https://files.eric.ed.gov/fulltext/ED497456.pdf

Simamoraa, Rustam E., Dewi Rotua Sidabutarb, Edy Surya; (2017). Improving Learning Activity and Students' Problem-Solving Skill through Problem Based Learning (PBL) in Junior High School International Journal of Sciences: Basic and Applied Research (IJSBAR) 33(2):321-331 https://www.researchgate.net/publication/317416532

Shih, Ju-Ling, Hui -chun chu, Gwo-Jen Hwang, Kinshuk; (2011). An investigation of attitudes of students and teachers about participating in a context-aware ubiquitous learning activity; British Journal of Educational Technology. Pp. 373-394; https://doi.org/10.1111/j.1467-8535.2009.01020.x

Tuimur, Hilda Ng'etich, Chemwei, Berbard (2015). Availability and Use of Instructional Materials in the Teaching of Conflict and Conflict Resolution in Primary Schools in Nandi North District, Kenya. 3(6): 224-234. https://files.eric.ed.gov/fulltext/ED560670.pdf

Udosen, Idongesit N., \& Ekukinam, Thelma U. (2013). Improvisation of Technological Instructional Media and Students' Performance in Primary Science in Nigerian Schools. World Conference on Science and Technology Education.

Wentzel, K. R. (2009). Peers and academic functioning at school. In K. Rubin, W. Bukowski, \& B. Laursen (Eds.), Handbook of peer interactions, relationships, and groups. Social, emotional, and personality development in context (pp. 531-547). New York, NY: Guilford Press. https://psycnet.apa.org/record/2008-19117-029

Wilson, Sophie(2002). Apply Language-Based Teaching Strategies in Science Class. Landmark School https://www.landmarkoutreach.org/strategies/apply-language-based

Yakob, M. Saiman, Sofiyan, R P Sari1, R A Z El Islami. (2020). The effectiveness of science experiment through multimedia teaching materials to improve students' critical thinking. Journal of Physics: Conference Series, Volume 1567, Issue 4, article id. 042018 (2020).

Zingiswa Mybert Monica Jojo. (2015). The Use of Indigenous Materials in the Teaching and Learning of Geometry. Journal of Communication 6(1):48-56. http://uir.unisa.ac.za/bitstream/handle/10500/21216/ 
